Pak. j. sci. ind. res. Ser. B: biol. sci. 2018 61B(2) 59-67

\title{
Sorption-Desorption Characteristics of Benzimidazole Based Fungicide Benomyl on Physicochemical Properties of Selected Pakistani Soils and their Minerals
}

\author{
Khuram Shahzad Ahmad \\ Department of Environmental Sciences, Fatima Jinnah Women University, Rawalpindi-46000, Pakistan
}

(received April 1, 2015; revised July 4, 2017; accepted July 10, 2017)

\begin{abstract}
A versatile cost-effective fungicide, Benomyl (Methyl \{1(butylamino)carbonyl $\}$-1H-benzimidazol2-ylcarbamate) has been utilised to investigate its sorption behaviour on physicochemical properties of soils, via batch equilibrium method. Linear and Freundlich adsorption isotherms were evaluated in two tested soils having values of slope $\mathrm{n}<1$ resembling the c-type curve. The distribution co-efficient $\mathrm{K}_{\mathrm{ads}}$ for adsorption was 2.93 and $14.35 \mathrm{~mL} / \mu \mathrm{g}$ both soils indicating low adsorption of Benomyl overall with relatively greater degree of adsorption on hilly soil and silt loam and lesser adsorption on sandy soil. Multan soils have more sand content (52\%) so it has less $\mathrm{K}_{\mathrm{d}}$ value. Desorption studies revealed that the adsorbed fungicides were firmly retained by soil particles and their adsorption was almost irreversible. Furthermore, the results were statistically evaluated through regression analysis and univariate ANOVA, also probability graphs were plotted to ensure the accuracy of the experimental data. The XRD analysis depicted an increase in basal spacing of pesticide in both soils.
\end{abstract}

Keywords: benomyl, sorption, desorption, physicochemical properties, soil organic matter

\section{Introduction}

Sorption studies of pesticides are required for understanding fate of pesticides in natural environment especially in the soil and ground water (Monkiedje and Spiteller, 2002; Konda et al., 2002). More than $98 \%$ insecticides and $95 \%$ herbicides reach non-targeted species and environmental compartments e.g. air, water, soil, nontargeted food and crops etc. (Lombardi et al., 2003). These pesticides are highly mobile and contaminate soil, surface water as well as ground water (Tariq et al., 2004). Thus environmental studies (behaviour and fate) of pesticides are necessary to preserve environment and reduce hazardous risk of pesticides contamination.

Adsorption and desorption mechanisms control soilpesticide interactions (Shariff, 2009) and also helpful in understanding the effects of controlled or uncontrolled distribution of pesticides in the soil. However, in different soils equilibrium phase between solution and sorption is used to assess adsorption and desorption process (Shariff, 2012). Nevertheless, the sorption process depends on chemistry of pesticides and the nature and properties of the soil components (Koskinen et al., 2002; Bailey et al., 1968).

Keeping in view importance of sorption studies of pesticides, the present study focuses on adsorptionE-mail: chemist.phd33@yahoo.com desorption characteristics of benzimidazole based fungicide Benomyl on selected agricultural soils of Pakistan. Benomyl fungicides are Benzimidazole derivatives. Benzimidazole fungicides are broad spectrum and systematic fungicides having a similar mode of action (Roy, 2002; Aharonson and Kafkai, 1975). Benzimidazole compounds are used for protection of various types of plants and crops including cereals, fruits, vegetables, ornamental plants etc. against fungal disease and effective against some important pathogens, such as Pithomyces chartarum, Sclerotinia sclerotiorum and Podosphaera leucotricha (Martin, 2005; Roy, 2002). In order to enhance agricultural productivity various pesticides are used in agricultural sector of Pakistan. (Methyl-\{1(butylamino)carbonyl\}-1H-benzimidazol2-ylcarbamate) is one of the frequently used pesticides on various crops, fruits and vegetables (Tariq et al., 2004).

Despite of prevalent use of pesticides in Pakistan, there is limited knowledge about environmental fate of these pesticides in terms of toxicity and persistence. Therefore, present research is designed to investigate the effect and behaviour of Benomyl on different agricultural Pakistani soils through adsorption and desorption studies, involving HPLC and XRD techniques. 


\section{Materials and Methods}

Chemicals. The solvents; acetone (99.9\%) and methanol (99.9\%), purchased from Merck (Germany) were utilised in this study. (Methyl $\{1$ (butylamino)carbonyl $\}-1 \mathrm{H}-$ benzimidazol-2-ylcarbamate) a white crystalline chemical of analytical standard which was prepared in the laboratory (Fig. 1). Sodium chloride and calcium chloride were used as background electrolyte.

Soil sampling procedures. Two soils were collected from cultivated soil areas of Punjab and Khyber Pakhtunkhwa, where there was no recent history of pesticide application. Soil 1 was collected from Multan (Chak no.136 WB Tehsil Harappa, District Multan). Soil 2 was collected from Ayubia, District Abbotabad, Khyber Pakhtunkhwa. These two soils had substantial differences representing a range of physicochemical properties (Table 1).

Soil preparation and physicochemical analysis. Sub samples of each soil were mixed thoroughly, air dried at room temperature for $24 \mathrm{~h}$, disaggregated manually using a marble mortar and a pestle. Individual soil sample passed through a 2-mm screen sieve and mixed manually to achieve homogeneity. Samples of homogenized soils were analysed for organic matter percentage, $\mathrm{pH}$, organic carbon content and other physicochemical



Fig. 1. Basic molecular structure of Methyl $\{1$ (butylamino)carbonyl $\}$-1H-benzimidazol2-ylcarbamate. properties following standard test method. The obtained data is depicted in Table 1. The moisture content was determined by the difference in the pre and post weights of soils after drying at $105^{\circ} \mathrm{C}$. In order to oxidize any volatile organic matter the soil samples were heated in the Ney Vulcan burnout furnace up to $400{ }^{\circ} \mathrm{C}$ for $24 \mathrm{~h}$ and from weight loss the organic matter content was deduced. Soil $\mathrm{pH}$ was measured by making the slurry of $10 \mathrm{~g}$ of dry soil in $10 \mathrm{~mL}$ de-ionized water. After one hour of contact time the $\mathrm{pH}$ of the slurry was measured using Orion 420 plus $\mathrm{pH}$ meter equipped with a glass electrode.

Sorption of methyl\{1(butylamino)carbonyl\}-1Hbenzimidazol-2-ylcarbamate on soils. All experiments were performed under isothermal conditions at $25 \pm 1$ ${ }^{\circ} \mathrm{C}$ and run in duplicates. All instruments were initially washed with acetone. Pesticide solutions were prepared by initially dissolving $10.3 \mathrm{mg}$ of pesticide in a few drops of methanol and then adding de-ionized water in $1 \mathrm{~L}$ volumetric flask to make up to the mark and stored at $4{ }^{\circ} \mathrm{C}$, whereas methyl $\{1$ (butylamino) carbonyl $\}-1 \mathrm{H}$ benzimidazol-2-ylcarbamate of different concentration having $0.25,0.5,0.75,1.0,2.5,5.0$ and $7.5 \mathrm{ppm}$ were prepared from this stock solution. Different concentrations of pesticide solution were taken to obtain greater accuracy of results from experimental data. Sorbent/ solution ratio was kept at 1:20. Depending on the desired fungicide concentration, $10 \mathrm{~mL}$ of $0.1 \mathrm{M}$ sodium chloride was added as background electrolyte in each concentration to simulate the ionic strength similar to that of natural soil solution. An aqueous solvent phase was also added in order to improve centrifugation and to minimize cation-exchange.

Each sample consisted of $0.5 \mathrm{~g}$ of soil or mineral mixed with $10 \mathrm{~mL}$ of pesticide solution in 1:10 soil/solution ratio, placed in a $15 \mathrm{~mL}$ Pyrex glass centrifuge tube, fitted with a screw cap. The tubes were continuously agitated on a Stuart Orbital Shaker at $90 \mathrm{rpm}$ for $24 \mathrm{~h}$ at room temperature $\left(25^{\circ} \mathrm{C}\right)$ in order to attain equilibrium. The adsorption equilibration process was done in duplicate for each concentration. In addition a blank

Table 1. Physicochemical properties of selected soils

\begin{tabular}{|c|c|c|c|c|c|c|c|c|c|}
\hline Sample & Location & Soil texture & $\mathrm{OM}$ & Clay & Sand & Silt & \multirow[t]{2}{*}{$\mathrm{pH}$} & \multirow[t]{2}{*}{$\mathrm{OC}$} & \multirow[t]{2}{*}{ Primary Crops } \\
\hline & \multicolumn{6}{|c|}{$(\%)$} & & & \\
\hline Soil 1 & Ayubia (KPK) & Silt loam & 6.51 & 44 & 24 & 41 & 7.6 & 3.79 & Wheat, Cotton \\
\hline Soil 2 & Multan (Punjab) & Loamy \& sandy & 1.89 & 12 & 52 & 13 & 8.1 & 1.10 & Maize, French beans \\
\hline
\end{tabular}

$* \mathrm{OM}=$ organic matter, $\mathrm{OC}=$ carbon content. 
sample containing only dissolved fungicides and 0.1 $\mathrm{M} \mathrm{NaCl}$ background electrolyte without any mineral or soil was prepared and treated in parallel with each set of batch experiment in order to quantify the losses and to account for possible degradation during adsorption process. Then each system containing equilibrated material was centrifuged at $3000 \mathrm{rpm}$ for $25 \mathrm{~min}$ at 25 ${ }^{\circ} \mathrm{C}$. Subsequently, the centrifuged tubes were decanted by filtering soil water suspension and clear aliquots were taken for analysis of the pesticides (Ali and Baugh, 2003).

Desorption studies. Desorption studies were conducted on the same fungicide soil solutions. After the sorption experiment, the remainder of the supernatant was decanted and the tubes were reweighed. Subsequently, $9 \mathrm{~mL}$ of freshly prepared $0.01 \mathrm{M} \mathrm{CaCl}_{2}$ solution was added to the soil remaining in the centrifuge tubes and shaken for $24 \mathrm{~h}$. Finally, HPLC, UV-visible spectrophotometer and XRD measurements were analysed.

HPLC. Concentration of Benomyl was analysed on HPLC (LC-20 AT UFLC by Schinal 24, Japan), $\mathrm{C}_{18}$ column $(100 \mathrm{~mm} \times 5.0 \mathrm{~mm}$ I.D., $4 \mu \mathrm{m}$ particle size $)$. Nova-pack guard column was used as precolumn. A mobile phase of methanol: water $(40+60, \mathrm{~V} / \mathrm{V})$ and $0.5 \%$ acetic acid, flow rate $1.5 \mathrm{~mL} / \mathrm{min}$, detector wavelength $=207 \mathrm{~nm}$, injection volume $=50 \mu \mathrm{L}$ and an ambient room temperature of $20^{\circ} \mathrm{C}$.

$\boldsymbol{U} \boldsymbol{V}$-vis spectrophotometer. The clear aliquots of sorbent: soil solutions were run on UV-vis spectrophotometer for analysis of Benomyl.

Data analysis. The amount of the Benomyl adsorbed ( $\mu \mathrm{g} / \mathrm{g}$ of soil) was calculated by using equations for sorption parameters and sorption coefficient for Linear and Freundlich isotherms (Martin, 2005; Roy, 2002; Bekbölet et al., 1999).

XRD analysis. XRD studies were performed in order to confirm the occurrence of adsorption of pesticide in soils and soil minerals. Basal spacing was checked whether showing an increase to detect the perpendicular or parallel arrangement of pesticide during its intercalation in soils.

\section{Results and Discussion}

Benomyl adsorption and desorption were studied by HPLC (Fig. 2-5).

Discussion of benomyl with soils. Sorption Kinetics. Two soils, soil 1 (KPK) and soil 2 (Multan, Pakistan) were selected for further investigation due to large variation in physicochemical property. Linear and Freundlich isotherms were studied in the current research. Isotherms were used to investigate the sorption kinetics of Freundlich and Linear equilibrium models (Table 2-3).

Values of $\mathrm{K}_{\mathrm{d}}$ for both soils were 14.35 and $2.93 \mu \mathrm{g} / \mathrm{mL}$, respectively. This shows moderate and weak sorption of Benomyl on both tested soils. The reason behind low adsorption of Benomyl on soil 2 is that it contains low organic matter (1.89) and less percentage of clay content (12) resulting in lesser adsorption sites (Laird et al., 1994). Adsorption is directly dependent on $\mathrm{K}_{\mathrm{oc}}$, also known as the leachability index. The $\mathrm{K}_{\mathrm{oc}}$ values for both soils depicted less mobility of Benomyl in them and thus lower leachability. $\mathrm{K}_{\text {foc }}$ also determines the mobile nature of Benomyl in soil layers. Table 2 shows that the predicted capacity for Benomyl retention normalized to the $\mathrm{OC}$ content (i.e. $\mathrm{K}_{\mathrm{foc}}$ ) differentiated
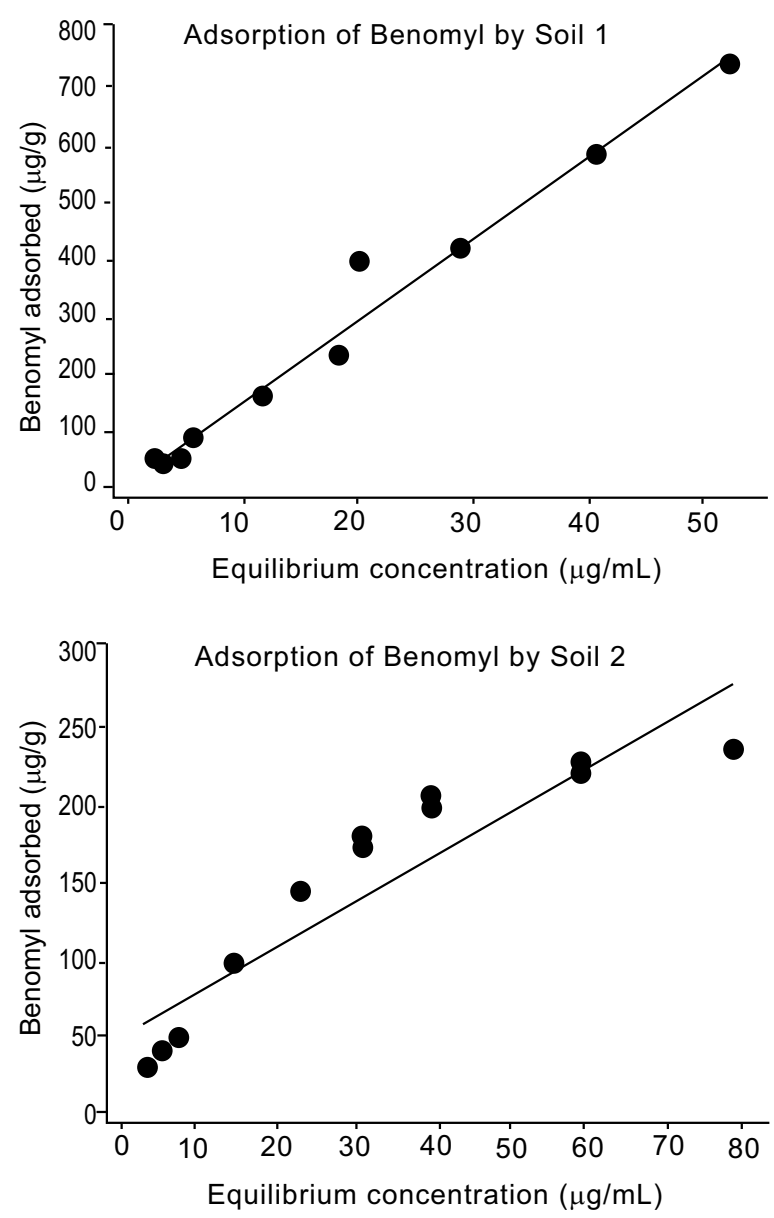

Fig. 2. Simple adsorption of Benomyl on 2 studied soil samples. 
significantly in these soils. When $\mathrm{K}_{\text {foc }}$ values are greater than $1000 \mu \mathrm{g} / \mathrm{mL}$, then movement of pesticides is higher in soils while values of $\mathrm{K}_{\text {foc }}$ between 150 and $500 \mu \mathrm{g} / \mathrm{mL}$ are indicative of medium mobility. Accordingly soil 1 with $\mathrm{K}_{\text {foc }}$ value 361 showed medium mobility while soil 2 having $K_{\text {foc }}$ value 1152 showed high mobility of Benomyl. If organic matter in soils had a common capacity for Benomyl, $\mathrm{K}_{\text {foc }}$ value might be expected to be nearly constant. Organic matter contents and organic carbon contents are related to each other but nature of organic compounds (polarity or aromacity) present in the soil can be different (Goring and Hamcker, 1972). $\mathrm{K}_{\mathrm{oc}}$ of KPK soil was found to be 378 and that of Multan soil was 266 , respectively. The Freundlich constant $\mathrm{K}_{\mathrm{f}}$ indicates the estimated capacity of Benomyl adsorption. Higher value of $\mathrm{K}_{\mathrm{f}}$ in soil 1 is indicative of lesser mobility. $\mathrm{K}_{\mathrm{f}}$ was higher in soil 1 due to higher organic matter.


Fig. 3. Freundlich isotherms of Benomyl adsorption on studies soils.
Gibbs free energy change $(\Delta \mathrm{G})$ can be used to judge the adsorption reaction. If the absolute value of $\mathrm{G}=40$ $\mathrm{kj} / \mathrm{mol}$, it indicates physical adsorption of fungicides with the soil. The $\Delta \mathrm{G}$ values of Benomyl with two soils ranged from -13.36 to $-12.49 \mathrm{kj} / \mathrm{mol}$ are suggesting that the physical adsorption took place. Benomyl is highly adsorbed on forest soil 1 as compared to the soils 2 . The different sorptive behaviours exhibited by Benomyl on soils are caused by the general physical/chemical properties of soil and pesticides solution. With increasing organic matter, organic carbon and $\mathrm{pH}$ of soil an increase in the adsorption of fungicide Benomyl to soil 1 occurred. Value of $n_{a}$ is inversely proportional to the sorption of pesticides in soils. Hence, soil 1 has lower value of $n_{a}$ as compared to soil 2. Table 3 shows the desorption parameters of Benomyl in soils. $\mathrm{K}_{\mathrm{d}(\mathrm{des})}$ values are 20.14 and $18.72 \mu \mathrm{g} / \mathrm{mL}$ for both soils. While $\mathrm{K}_{\mathrm{f}(\mathrm{des})}$ values are 14.87 and $16.28 \mu \mathrm{g} / \mathrm{mL}$ for these soils. $\mathrm{H}$ or the hysteresis coefficient is the ratio between $\mathrm{n}_{\mathrm{d}}$ and $\mathrm{n}_{\mathrm{a}}$ and measures the irreversibility of adsorption process. The value of $\mathrm{H}$ closer to 1 indicates that the process of desorption occurred as quickly as adsorption in soils. The values of $\mathrm{R}^{2}$ closer to 1 indicate the goodness of fitness of the experimental data.

Physicochemical analysis. An increase in soil organic matter displayed an increase in the adsorption coefficients. Hence organic matter showed a positive correlation with adsorption coefficient. Soil 1 showing higher organic matter also exhibited higher adsorption coefficient. Overall, a positive correlation of adsorption coefficients was observed with both organic matter and total organic carbon. While $\mathrm{pH}$ showed a negative correlation with adsorption. Soil 1 with higher adsorption coefficient had lower $\mathrm{pH}$ while soil 2 had higher

Table 2. Adsorption coefficients of Benomyl in selected soils

$\begin{array}{llllllllll}\text { Soil } & \mathrm{K}_{\mathrm{d}} & \mathrm{R}^{2} & \mathrm{~K}_{\mathrm{oc}} & \mathrm{K}_{\mathrm{f}} & \mathrm{n}_{\mathrm{a}} & \mathrm{R}^{2} & \mathrm{~K}_{\text {foc }} & \mathrm{K}_{\mathrm{OM}} & \Delta \mathrm{G}\end{array}$

$\begin{array}{llllllllll}\text { Soil } 1 & 14.35 & 0.97 & 378 & 13.7 & 0.98 & 0.97 & 361 & 220 & -13.36\end{array}$

$\begin{array}{llllllllll}\text { Soil } 2 & 2.934 & 0.86 & 266 & 12.7 & 1.38 & 0.97 & 1154 & 155 & -12.49\end{array}$

Table 3. Desorption coefficients of Benomyl in selected soils

\begin{tabular}{lllllll}
\hline \hline Soil & $\mathrm{K}_{\mathrm{d}(\mathrm{des})}$ & $\mathrm{R}^{2}$ & $\mathrm{~K}_{\mathrm{f}(\mathrm{des})}$ & $\mathrm{n}$ & $\mathrm{R}^{2}$ & $\mathrm{H}$ \\
\hline Soil 1 & 20.14 & 1.00 & 14.87 & 0.91 & 0.98 & 0.93 \\
Soil 2 & 18.72 & 0.98 & 16.28 & 0.97 & 0.98 & 0.75 \\
\hline \hline
\end{tabular}


$\mathrm{pH}$. Alkaline soils tend to show lesser adsorption. Soil texture also plays a crucial role in the adsorption capacity of a particular soil. Clay and silt content also play a positive role in adsorption process. Soil 1 contained a higher percentage of clay and silt content while soil 2 had lesser content. Sand content shows negative correlation with sorption process. Soil 2 contained a higher percentage of sand content while soil 1 had lesser percentage.

Statistical analysis. Statistical analysis was performed on all soil samples for the $K_{d}$ values and their corresponding physiochemical properties including $\mathrm{pH}$ and OC (Fig. 6) (Table 4). Regression analysis on the samples displayed the relationship between them. The results showed a negative correlation with $\mathrm{pH}(\mathrm{r}=-0.1)$ while positive correlation with $\mathrm{OC}(\mathrm{r}=0.1)$. This confirms the fact that high OC would result in higher rate of adsorption property while higher $\mathrm{pH}$ will decrease this property. It also justifies our experimental results
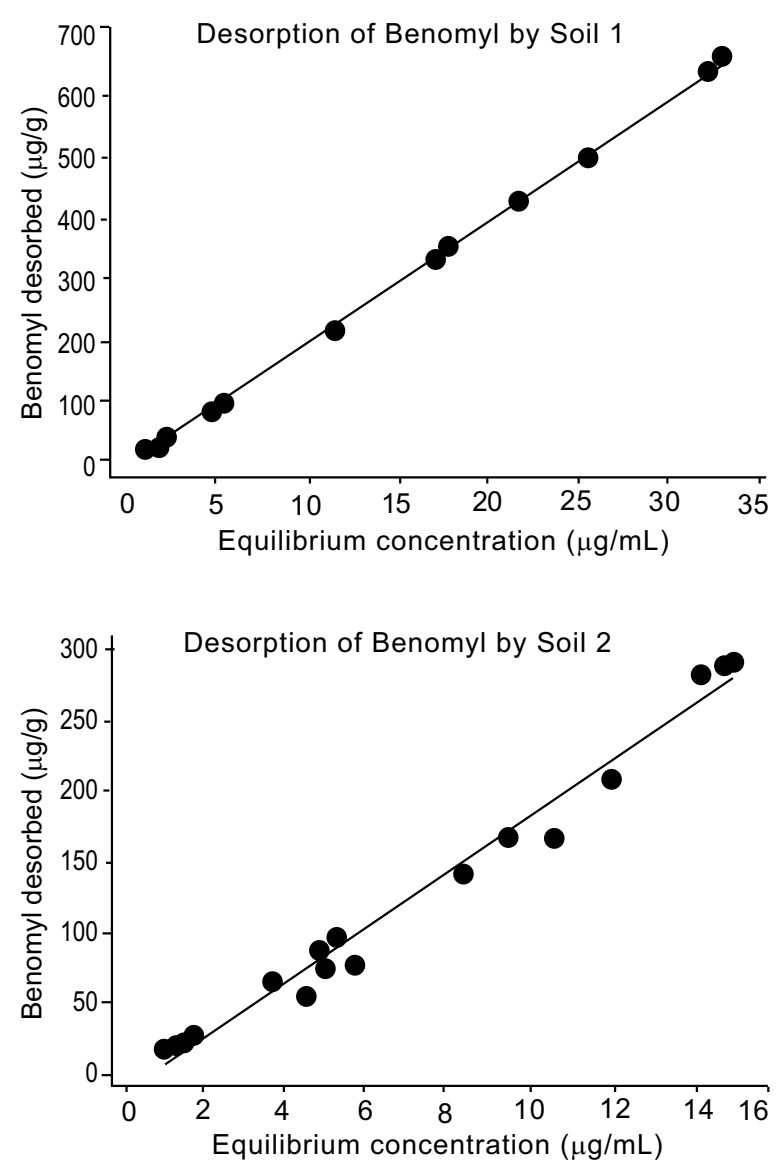

Fig. 4. Simple desorption of Benomyl on 2 studied soil samples.
Table 4. Linear regression and correlation for Chlorfluazuron adsorption

\begin{tabular}{llllll}
\hline \hline $\begin{array}{l}\text { Adsorption } \\
\text { coefficient }\end{array}$ & $\begin{array}{l}\text { Pro- } \\
\text { perty } \\
\text { (x) }\end{array}$ & $\begin{array}{l}\text { Correlation } \\
\text { coefficient } \\
\text { (r) }\end{array}$ & $\begin{array}{l}\text { Probability } \\
\text { level } \\
(\mathrm{p})\end{array}$ & $\begin{array}{l}\text { Inter- } \\
\text { cept } \\
\text { (a) }\end{array}$ & $\begin{array}{l}\text { Slope } \\
\text { (b) }\end{array}$ \\
\hline $\mathrm{K}_{\mathrm{d} \text { ads }}$ & $\mathrm{pH}$ & -1 & 0.08 & 8.22 & -0.04 \\
& $\mathrm{OC}$ & 1 & 0.08 & 0.70 & 0.40 \\
& $\% \mathrm{C}$ & 1 & 0.07 & 0.40 & 0.23 \\
\hline \hline
\end{tabular}

that the soil sample 1 with highest value of $\mathrm{K}_{\mathrm{d}}(14.35$ $\mu \mathrm{g} / \mathrm{mL}$ ) has the higher organic matter (6.51) in it. This shows a direct proportionality between organic matter and adsorption capacity of soil.

One-way ANOVA was also performed on the soil samples with their respective $K_{d}$ values. The parameters studied included: mean square (MS), $P$-value (probability), degree of freedom (df), sum of squares (SS), F statistics (F) and $\mathrm{F}$ critical values (F crit) (Table 5). The $P$-value was greater than the alpha value $(\alpha)(0.05)$.
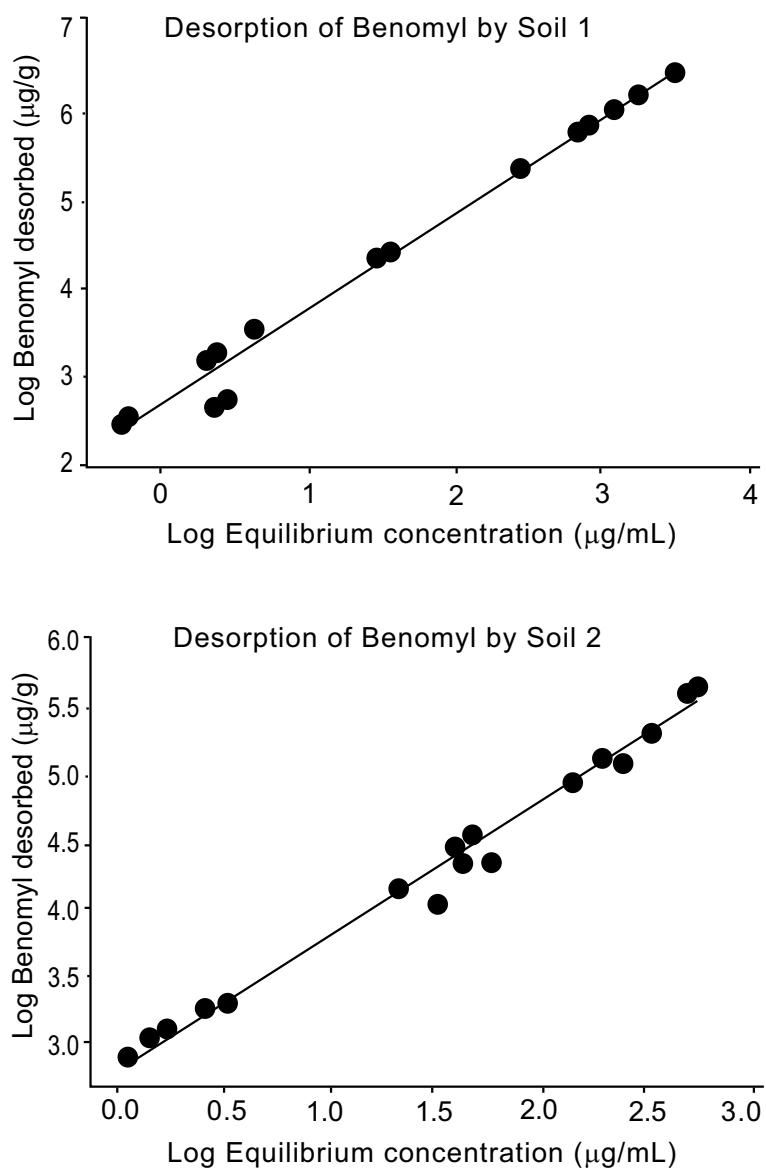

Fig. 5. Freundlich isotherms of Benomyl desorption by studied soils. 


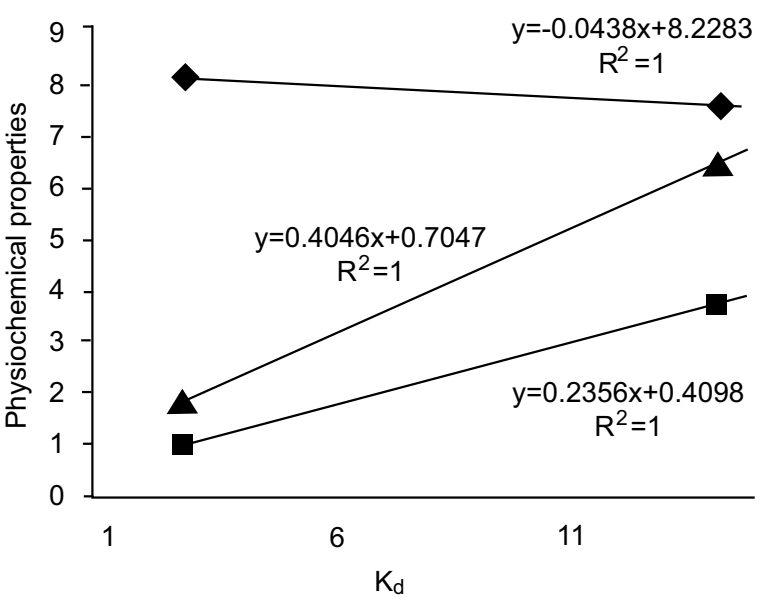

$\mathrm{pH} \triangle \mathrm{O} \mathrm{OM}$

Fig. 6. Relationship of physiochemical properties of soil with $\mathrm{K}_{\mathrm{d}}$.

The F crit value was found 7.7 while the F statistics value was lower than it (0.8). This lower value of $F$ statistics proves that the experimental values are correct and in an standard range. Furthermore, residual and normal probability plots were obtained in order to observe the goodness of fit of the experimental results (Fig. 7 and Fig. 8). Normal probability plots display that the data has normal distribution and the residual plots display a constant variance of the data.

XRD results. The XRD analysis of the pesticide blank samples, blank soils and soil treated with pesticide were carried out (Yalçin and Apak, 2006). The pesticide was checked for its position in soils and minerals at a specific spacing. The pesticide can either be perpendicular or parallel inserted into the soils. XRD helps to detect the penetrating patterns of pesticide, thus confirming the occurrence of adsorption. In this experiment we checked d001 spacing. Specific soil minerals were used in the XRD studies due to their environmental importance. For example Bentonite was used because this mineral

Table 5. Univariate ANOVA analysis of soil samples with $\mathrm{K}_{\mathrm{d}}$

\begin{tabular}{lcccccc}
\hline \hline $\begin{array}{l}\text { Source of } \\
\text { variation }\end{array}$ & SS & df & MS & F & $P$-value & F crit \\
\hline $\begin{array}{l}\text { Between } \\
\text { groups }\end{array}$ & 7.7 & 1 & 7.7 & 0.83 & 0.41 & 7.7 \\
$\begin{array}{l}\text { Within } \\
\text { groups }\end{array}$ & 37 & 4 & 9.2 & - & - & - \\
\hline \hline
\end{tabular}

is used extensively in different environmental engineering applications and present naturally in arid areas. Goethite and aluminium oxide minerals were used because they are a byproduct of weathering of clay minerals. As most agricultural soils in Pakistan are high in clay content hence, their breakdown product is more dominantly having these Goethite and aluminium oxide minerals. Silica mineral used in XRD studies as silicates is very abundant in earth's crust hence it is a very crucial mineral for interaction of any chemical on earth's surface such as pesticide.

Multan soil. Results of XRD studies for Multan soil are given in Fig. 9a and Table 6. Sorption of pesticides with soil was measured by the change in basal spacing in XRD. The basal spacing of Multan soil expands from 9.99 to $14.15 \mathrm{~A}^{\circ}$ with Benomyl. The reason for larger increase in basal spacing of soil might be due to perpendicular arrangement of pesticide into interlayer whereas relative smaller difference indicates parallel arrangement of pesticide into interlayer.

KPK soil. Results of XRD studies for KPK are given in Fig. 9b and Table 6. Sorption of pesticides with soil


Fig. 7. Residual plots of $K_{d}$ with physiochemical properties of soil samples (A) Kd-pH residual plot. (B) $\mathrm{K}_{\mathrm{d}}-\mathrm{OM}$ (organic matter) residual plot. (C) $\mathrm{K}_{\mathrm{d}}-\mathrm{OC}$ (total organic carbon) residual plot. 
was measured by the change in basal spacing in XRD. The basal spacing of KPK soil expands from 9.97 to $14.16 \mathrm{~A}^{\circ}$ with Benomyl. The reason for larger increase in basal spacing of soil might be due to perpendicular arrangement of pesticide into interlayer of soil whereas relative smaller difference indicates parallel arrangement of pesticide into interlayer of soil. In some cases there is no penetration shown in XRD results even HPLC technique show sorption, it may be due to surface adsorption.

Goethite mineral. Results of XRD studies for Goethite mineral are given in Fig. 10a and Table 6. Sorption of pesticides with soil was measured by the change in basal spacing in XRD. The basal spacing of Goethite mineral expands from 10.3 to $14.16 \mathrm{~A}^{\circ}$ with Benomyl. This result indicates that pesticide expands the $\mathrm{d}(001)$ spacing.
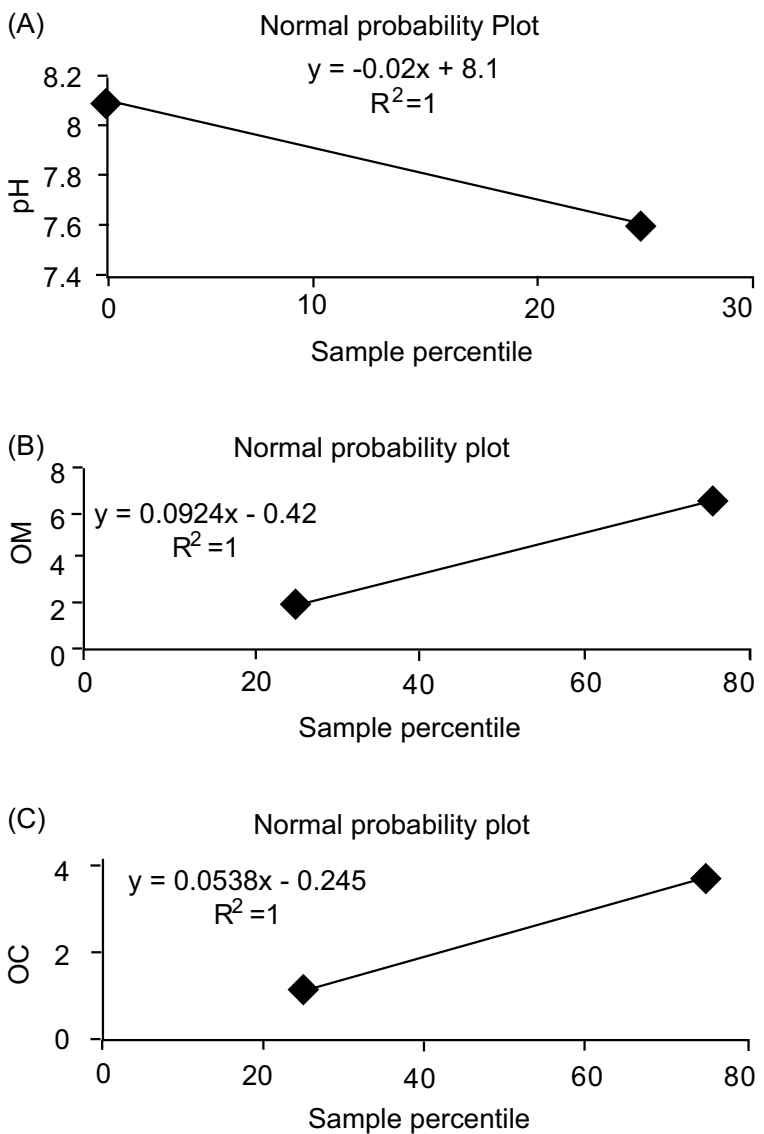

Fig. 8. Normal probability plots of sample percentiles with sample physiochemical properties. (A) Probability plot of $\mathrm{pH}$ (B) Probability plot of organic matter. (C) Probability plot of total organic carbon.
Bentonite mineral. Results of XRD studies for Bentonite mineral are given in Fig. 10b and Table 5. Sorption of

Table 6. Basal spacing $\left(\mathrm{A}^{\circ}\right)$ for clay minerals and soils

\begin{tabular}{lllllll}
\hline \hline $\begin{array}{l}\text { Basal } \\
\text { spacing }\end{array}$ & $\begin{array}{l}\text { Multan } \\
\text { soil }\end{array}$ & $\begin{array}{l}\text { KPK } \\
\text { Soil }\end{array}$ & $\begin{array}{l}\text { Geothite } \\
\text { mineral }\end{array}$ & $\begin{array}{l}\text { Bento- } \\
\text { nite } \\
\text { mineral }\end{array}$ & $\begin{array}{l}\text { Silica } \\
\text { mine- } \\
\text { ral }\end{array}$ & $\begin{array}{l}\text { Alumi- } \\
\text { nium } \\
\text { oxide } \\
\text { mineral }\end{array}$ \\
\hline $\begin{array}{l}\text { Untreated } \\
\mathrm{d}(001)\end{array}$ & 9.99 & 9.97 & 10.03 & 12.06 & 0 & 3.46 \\
$\begin{array}{l}\text { Treated } \\
\text { with }\end{array}$ & 14.15 & 14.16 & 14.16 & 12.37 & 0 & 4.54 \\
$\begin{array}{l}\text { Benomyl } \\
\mathrm{d}(001)\end{array}$ & & & & & & \\
\hline \hline
\end{tabular}
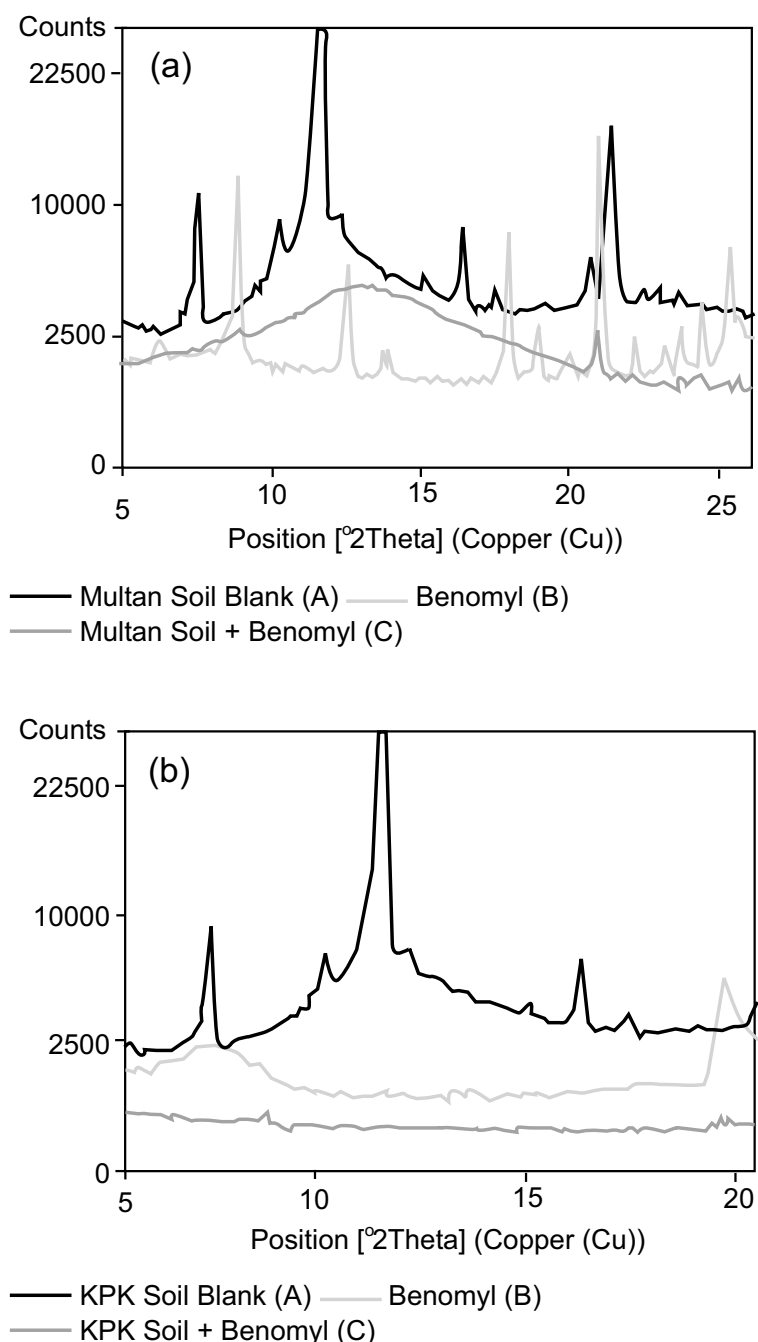

Fig. 9. (a) Multan soil (A) Untreated (B) Benomyl (C) Treated with Benomyl. (b) KPK Soil (A) Untreated (B) Benomyl (C) Treated with Benomyl. 

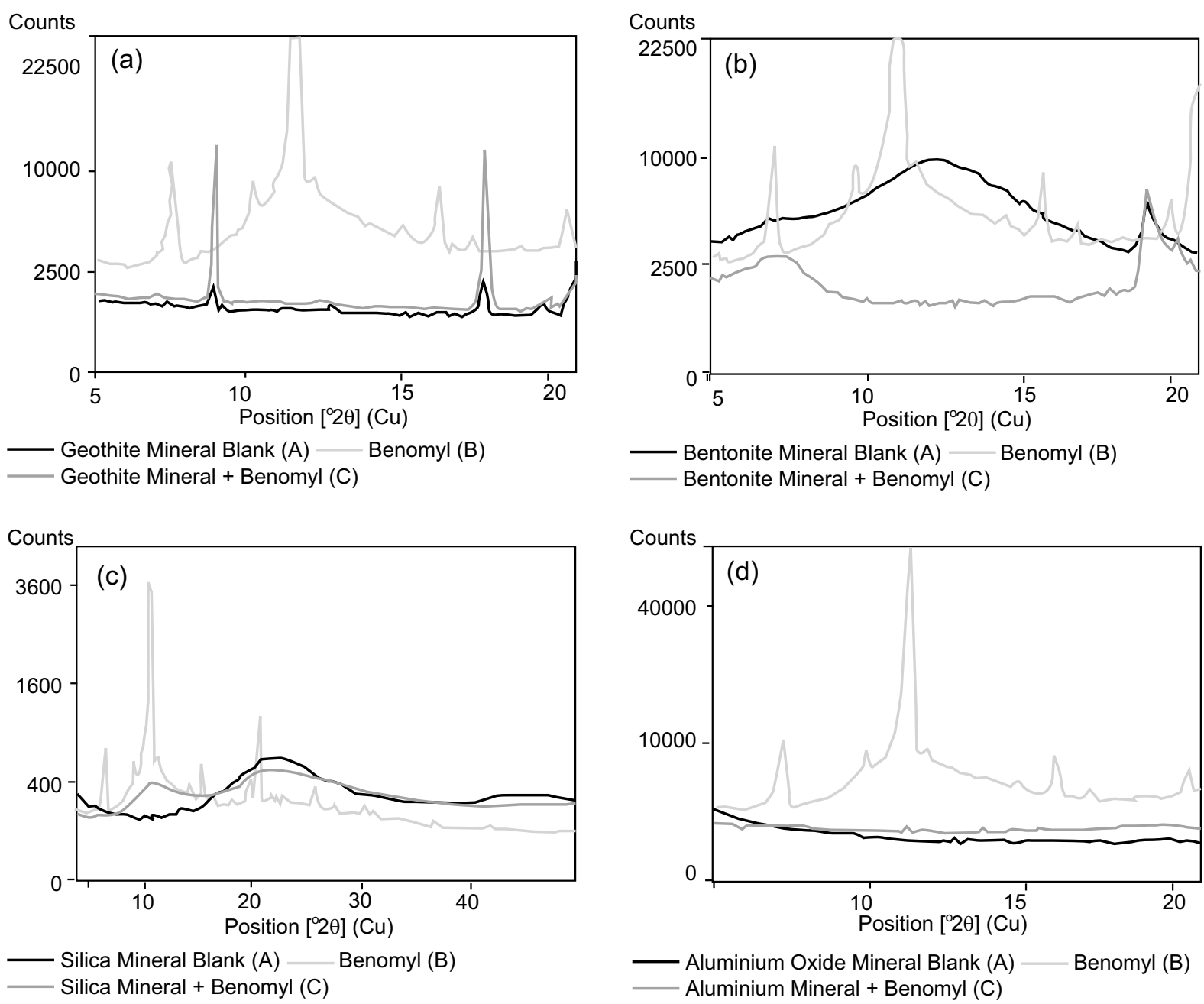

Fig. 10. (a) Geothite mineral (A) Untreated (B) Benomyl (C) Treated with Benomyl; (b) Bentonite mineral (A) Untreated (B) Benomyl (C) Treated with Benomyl; (c) Silica Mineral (A) Untreated (B) Benomyl (C) Treated with Benomyl and (d) Aluminium oxide mineral (A) Untreated (B) Benomyl (C) Treated with Benomyl.

pesticides with mineral was measured by the change in basal spacing in XRD. The basal spacing of bentonite mineral expands from 12.06 to $12.37 \mathrm{~A}^{\circ}$. This result indicates pesticide expands the $\mathrm{d}(001)$-spacing.

Silica mineral. Results of XRD studies for silica mineral are given in Fig. 10c and Table 6. Sorption of pesticides with mineral did not show any major change in the basal spacing of silica mineral. It can be concluded that intercalation of Benomyl pesticides with silica mineral would not occur that is why silica mineral didn't show any expansion of the basal spacing.

Aluminium oxide mineral. Results of XRD studies for aluminium oxide mineral are given in Fig. 10d and
Table 6. Sorption of pesticides with mineral was measured by the change in basal spacing in XRD. The basal spacing of aluminium oxide mineral expands from 3.46 to $4.54 \mathrm{~A}^{\circ}$. This result indicates that pesticide expands the $\mathrm{d}(001)$-spacing.

\section{Conclusion}

The research is notably demonstrating that Benomyl based fungicide, (Methyl $\{1$ (butylamino)carbonyl\}-1Hbenzimidazol-2-ylcarbamate) had weak-to-moderate adsorption capability in different geographical soils due to the factor of readily leaching. The adsorption and desorption of this fungicide in soil samples effectively revealed the Freundlich isotherm and significantly 
depended on the characteristics of soils. Particularly, soil $\mathrm{pH}$ value, organic carbon, clay contents and soil organic matters are dependable for the degree of adsorption of this fungicide on soil samples. The extent of adsorption increased as $\mathrm{pH}$ value decreased, while the capacity of adsorption increased as organic carbon, clay contents and organic matters increased. The observed adsorption-desorption behaviour of (Methyl $\{1$ (butylamino)carbonyl $\}-1 \mathrm{H}-$ benzimidazol2-ylcarbamate) suggests that physicochemical properties of soils are responsible for its controlled binding capabilities. Furthermore, statistical analysis proved the dependency of adsorption coefficient on soil's physiochemical parameters. The XRD analysis depicted an increase in basal spacing in both soils confirming the occurrence of adsorption. While the XRD studies on soil minerals separately indicated that silica mineral did not show any interaction with Benomyl. Hence no increase in basal spacing was observed in this case. This study can set the future course of action of different studies on pesticide in soils and ground water in Pakistan.

\section{Acknowledgement}

The authors acknowledge University of Manchester, UK, Allama Iqbal Open University Islamabad, Pakistan and Higher Education Commission of Pakistan for financial support.

\section{References}

Aharonson, N., Kafkafi, U. 1975. Adsorption of benzimidazole fungicides on montmorillonite and kaolinite clay surfaces. Journal of Agricultural and Food Chemistry, 23: 434-437.

Ali, M.A., Baugh, P.J. 2003. Sorption-desorption studies of six pyrethroids and mirex on soils using GC/MSNICI. International Journal of Environmental Analytical Chemistry, 83: 923-933.

Bailey, G.W., White, J.L., Rothberg, T. 1968. Adsorption of organic herbicides by montmorillonite: Role of $\mathrm{pH}$ and chemical character of adsorbate. Soil Science Society of America Journal, 32: 222-234.

Bekbölet, M., Yenigün, O., Yücel, I. 1999. Sorption studies of 2, 4-D on selected soils. Water, Air, \& Soil Pollution, 111: 75-88.

Goring, C.A., Hamcker, J.W. 1972. Organic Chemicals in the Soil Environment, 968 pp. Marcel Decker
Inc., New York, USA.

Konda, L.N., Czinkota, I., Fuleky, G., Morovjan, G. 2002. Modeling of single-step and multistep adsorption isotherms of organic pesticides on soil. Journal of Agricultural and Food Chemistry, 50: 7326-7331.

Koskinen, W.C., Rice, P.J., Anhalt, J.A., Sakaliene, O., Moorman, T.B., Arthur, E.L. 2002. Sorptiondesorption of "aged" sulfonylaminocarbonyl triazolinone herbicides in soil. Journal of Agricultural and Food Chemistry, 50: 5368-5372.

Laird, D.A., Yen, P.Y., Koskinen, W.C., Steinheimer, T.R., Dowdy, R.H. 1994. Sorption of atrazine on soil clay components. Environmental Science and Technology, 28: 1054-1061.

Lombardi, B., Baschinim, M., Sanchez, R.T. 2003. Optimization of parameters and adsorption mechanism of thiabendazole fungicide by a montmorillonite of North Patagonia, Argentina. Applied Clay Science, 24: 43-50.

Martin, N.A. 2005. Pesticide Resistance: Prevention and Management Strategies 2005. New Zealand Plant Protection Society Inc., Hastings, New Zealand.

Monkiedje, A., Spiteller, M. 2002. Sorptive behavior of the phenylamide fungicides, mefenoxam and metalaxyl, and their acid metabolite in typical Cameroonian and German soils. Chemosphere Journal, 49: 659-668.

Roy, K.N. 2002. Chemistry of Pesticides, 346 pp, CBS Publishers and Distributors, New Delhi, India.

Shariff, R.M. 2012. Effect of co-pesticide on adsorptiondesorption process on agricultural soils. International Journal of Modern Engineering Research, 2: 247-259.

Shariff, R.M. 2009. The study of adsorption and desorption of picloram on six agricultural soils. Journal of University of Anbar for Pure Science, 3: 23-27.

Tariq, M.I., Afzal, S., Hussain, I. 2004. Adsorption of pesticides by salorthids and comborthids of Punjab, Pakistan. Toxicological and Environmental Chemistry, 86: 247-264.

Yalçin, S., Apak, R. 2006. Chromium speciation analysis by separation of $\mathrm{Cr}$ (III) from $\mathrm{Cr}(\mathrm{VI})$ on a XAD sorbent derivatized with shellac: a natural polymer. International Journal of Environmental Analytical Chemistry, 86: 915-929. 